\title{
Cobalt(III)-oxo cubane clusters as catalysts for oxidation of organic substrates
}

\author{
BIRINCHI KUMAR DAS ${ }^{\mathrm{a}, *}$ and RAJESH CHAKRABARTY ${ }^{\mathrm{b}}$

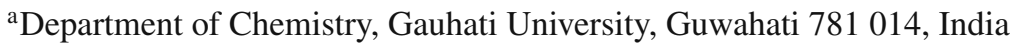 \\ ${ }^{b}$ Present address: Department of Chemistry, University of Utah, Salt Lake City, Utah 84112, USA \\ e-mail: Birinchi.Das@hotmail.com; rajeshch2001@yahoo.co.in
}

\begin{abstract}
Transition metal coordination complexes play a vital role as catalysts in the oxidation of organic substrates including renewable chemicals in an economically viable and environmentally friendly way. Here we highlight the preparation, characterization and application of oxo-cubane complexes of cobalt(III) as oxidation catalysts using air and water as oxidants. Cobalt(III)-oxo complexes of the type $\mathrm{Co}_{4} \mathrm{O}_{4}\left(\mathrm{O}_{2} \mathrm{CR}\right)_{4} \mathrm{~L}_{4}$ have been prepared by a general method and these have been characterized by analytical, spectroscopic, electrochemical and crystallographic methods. These soluble complexes have shown promising utility as catalysts in the aerobic oxidation of side chains of alkylaromatic hydrocarbon compounds. Oxidation of neat ethylbenzene has shown very high conversion and selectivity for acetophenone formation. On the other hand, oxidation of $p$-xylene has been found to yield both $p$-toluic acid and terephthalic acid. It is also possible to oxidize $p$-xylene in an aqueous medium under moderate applied $\mathrm{O}_{2}$ pressure. Selective epoxidation of $\alpha$-pinene with air as the oxidant also takes place with the cobalt(III)-based homogeneous catalysts.
\end{abstract}

Keywords. Cobalt(III) cubane; aerobic oxidation; pinene epoxidation; alkylaromatic oxidation; homogeneous catalysis.

\section{Introduction}

Transition metal coordination compounds have numerous applications among which an important one is in the catalysis of various reactions. Catalytic use of these compounds is particularly pre-eminent in reactions involving the oxidation of organic compounds via $\mathrm{C}-\mathrm{H}$ activation. Along with other important metals such as copper, iron, vanadium, osmium, etc., cobalt is active as a catalyst in the oxidation of substrates including alkylaromatics, alkenes and alcohols. ${ }^{1}$ Several industrial reactions make use of cobalt-based catalysts. ${ }^{2}$ Use of cobalt(II) salts and complexes is common in the published literature. The resultant processes utilize the +3 oxidation state of the metal in completing the catalytic cycle, but instances of either cobalt(III) salts or complexes being used in organic oxidation are rather rare. Ratnasamy et al. ${ }^{3}$ have reported the selective oxidation of $p$-xylene to terephthalic acid by trinuclear oxo-bridged cluster complexes of cobalt(II/III) and manganese(II/III) including mixed-Co/Mn species in presence of dioxygen. Oxo-bridged cluster complexes

\footnotetext{
${ }^{*}$ For correspondence
}

of transition metals have also been the subject of studies because these complexes may help in understanding the redox and ligand substitution reactions in metal catalysed autoxidation processes. ${ }^{4}$ Clearly, metal cluster complexes of cobalt are of particular interest because of their catalytic activity towards autoxidation of various aromatic hydrocarbons. Trinuclear cobalt clusters, $\left[(\mathrm{py})_{3} \mathrm{Co}_{3} \mathrm{O}(\mathrm{OAc})_{5} \mathrm{OR}\right]\left[\mathrm{PF}_{6}\right]$ have been used as catalyst precursors for the autoxidation of toluene in acetic acid containing $\mathrm{LiBr}$ with $\mathrm{O}_{2}$ as the oxidant to produce benzoic acid. ${ }^{5}$

Since cobalt-oxo clusters of different nuclearities may form under a given oxidative synthetic condition, it appeared important for us to identify the complex species that may play an active role in oxidation catalysis. Presence of the oxide ion as a ligand in these systems favours the formation of cobalt(III) complexes, but existence of the metal in the +4 oxidation state also cannot be ruled out. Presence of nitrogen bases as probable ligands in the oxidizing preparative condition favours the formation of cobalt(III) complexes of reversible redox stability. Oxo-bridged transition metal complexes with ancillary $\mathrm{N}$-and $\mathrm{O}$-donor ligands are of considerable interest to synthetic inorganic chemists because of their interesting structural motifs as well as 
due to their magnetic, optical, and catalytic properties and biological relevance. ${ }^{6}$ The most common core units encountered in such tetranuclear clusters are $\left[\mathrm{M}_{4}\left(\mu_{3^{-}}\right.\right.$ $\left.\mathrm{O})_{2}\right](\mathbf{I}),\left[\mathrm{M}_{4}\left(\mu_{3}-\mathrm{O}\right)_{3}\right]$ (II) and $\left[\mathrm{M}_{4}\left(\mu_{3}-\mathrm{O}\right)_{4}\right]$ (III). Manganese complexes of type III are well-studied because of their role as durable abiotic catalysts for the generation of oxygen and hydrogen from water by photolytic water splitting. ${ }^{7}$ butterfly (I)<smiles></smiles>

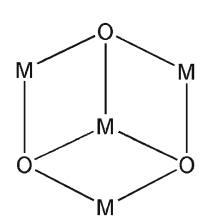

incomplete cubane(II) cubane (III)

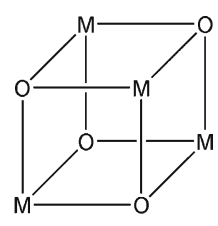

Oxo-carboxylato cobalt(III) clusters having a cubane-like core (III) have been found to be important in view of their promising activities in the catalytic oxidation of diverse organic substrates. ${ }^{8-13}$ The first example of cobalt(III) complexes of the above type was $\left[\mathrm{Co}_{4} \mathrm{O}_{4}\left(\mathrm{O}_{2} \mathrm{CMe}\right)_{2}(\text { bpy })_{4}\right]^{2+}$ (bpy $=2,2^{\prime}$-bipyridine) ${ }^{14}$ The complex $\mathrm{Co}_{4} \mathrm{O}_{4}\left(\mathrm{O}_{2} \mathrm{CMe}\right)_{4}(\mathrm{py})^{4}$ having the same $\left[\mathrm{Co}_{4} \mathrm{O}_{4}\right]^{4+}$ core was later isolated from a mixture of several other species formed by direct ozonolysis of cobalt(II) acetate in $\mathrm{H}_{2} \mathrm{O} / \mathrm{AcOH} /$ pyridine followed by precipitation with $\mathrm{NH}_{4} \mathrm{PF}_{6} .{ }^{15}$ Our interests on cobalt(III) cubane-like clusters of the type $\mathrm{Co}_{4} \mathrm{O}_{4}\left(\mathrm{O}_{2} \mathrm{CR}\right)_{4} \mathrm{~L}_{4}$, where $\mathrm{R}$ is methyl or an aryl group and $\mathrm{L}$ is either pyridine or a substituted pyridine ligand, originated from their relevance in oxidation catalysis. A highly efficient heterogeneous catalyst prepared by supporting a cobalt(III) species was earlier found to show very high conversion and selectivity in the aerobic oxidation of alkylaromatic hydrocarbons. ${ }^{16}$ Detailed studies have suggested that the metal complex is likely to belong to the type $\mathrm{Co}_{4} \mathrm{O}_{4}\left(\mathrm{O}_{2} \mathrm{CR}\right)_{4} \mathrm{~L}_{4} \cdot{ }^{17}$ In the course of our work several complexes of this class have been prepared by a convenient method and characterized by a variety of techniques. More importantly, it has been found that they act as homogeneous catalysts in the oxidation of organic substrates such as alkylaromatics, alcohols and alkenes with air, oxygen or tert-butyl hydroperoxide (TBHP) as oxidants. ${ }^{8,9,12,13}$ It is also possible to immobilize the complexes on mesoporous silica to obtain stable heterogeneous catalysts for the same reactions. ${ }^{10,11}$

In this paper, we discuss the synthesis and physicochemical characteristics of $\mathrm{Co}$ (III)-oxo cubane-like clusters of the type $\mathrm{Co}_{4} \mathrm{O}_{4}\left(\mathrm{O}_{2} \mathrm{CR}\right)_{4} \mathrm{~L}_{4}$. The role of these complexes in catalytic oxidation under homogeneous conditions is also discussed briefly.

\section{Preparation of $\mathrm{Co}_{4} \mathrm{O}_{4}\left(\mathrm{O}_{2} \mathrm{CR}\right)_{4} \mathrm{~L}_{4}$}

The synthetic strategy for the preparation of tetranuclear $\mathrm{Co}(\mathrm{III})$-oxo complexes of the type $\mathrm{Co}_{4} \mathrm{O}_{4}\left(\mathrm{O}_{2} \mathrm{CR}\right)_{4} \mathrm{~L}_{4}$, with $\mathrm{R}=\mathrm{CH}_{3}, \mathrm{C}_{6} \mathrm{H}_{5}$, or a 4substituted aryl group and $\mathrm{L}=$ pyridine or a 4substituted pyridine, involves the reaction of $\mathrm{Co}\left(\mathrm{NO}_{3}\right)_{2}$. $6 \mathrm{H}_{2} \mathrm{O}$ with two equivalents of the sodium salt of a carboxylic acid, $\mathrm{NaO}_{2} \mathrm{CR}$ and one equivalent of the chosen $\mathrm{N}$-donor ligand - pyridine (py), 4-cyanopyridine (4CNpy), 4-methylpyridine (4-Mepy) or 4-ethylpyridine (4-Etpy) - followed by $\mathrm{H}_{2} \mathrm{O}_{2}$-oxidation of $\mathrm{Co}^{2+}$ at an elevated temperature in commercial grade methanol. ${ }^{9}$ Oxidation of the pink solution forming at the beginning of the reaction with excess $\mathrm{H}_{2} \mathrm{O}_{2}$ leads to an olive green solution from which dark olive green $\mathrm{Co}$ (III) complexes of the above type may be isolated. Scheme 1 summarizes the synthetic route followed by us to obtain the cobalt(III)-oxo clusters in good to very good yield. In most cases, particularly when $\mathrm{R}$ is an aryl group, the complexes are found to precipitate out during the course of the reaction. However, isolated product yields are low in most cases. In view of this, we have developed an alternative work-up procedure to optimize product yields. In this improved isolation procedure the reaction mixtures obtained as described in scheme 1 are concentrated via evaporation and extracted with $\mathrm{CH}_{2} \mathrm{Cl}_{2}$. The solid products may then be obtained from the $\mathrm{Na}_{2} \mathrm{SO}_{4}$-dried $\mathrm{CH}_{2} \mathrm{Cl}_{2}$ solutions

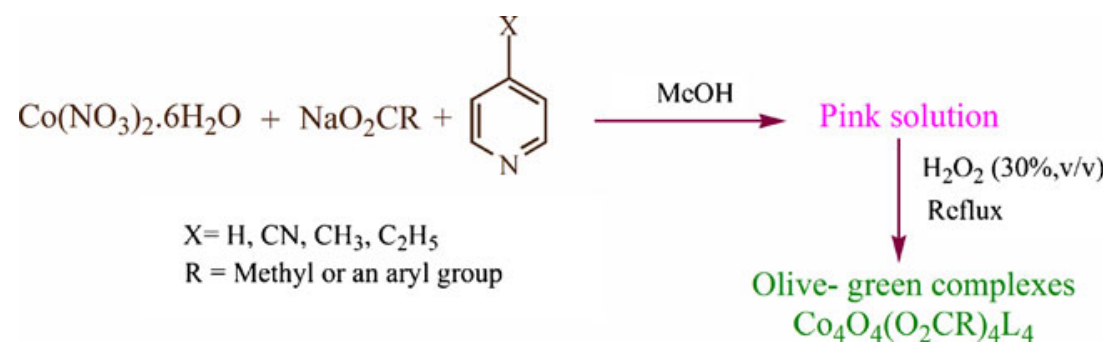

Scheme 1. General scheme for the synthesis of cubane-like cobalt(III)-oxo clusters. 
by adding petroleum ether as the precipitating solvent. This procedure also ensures the isolation of the cubane complexes without co-crystallizing sodium salts and solvent molecules (vide infra).

The synthetic method developed by us is thus quite simple because in all cases we are able to use $\mathrm{Co}\left(\mathrm{NO}_{3}\right)_{2} \cdot 6 \mathrm{H}_{2} \mathrm{O}$ in $\mathrm{MeOH}$ as the starting material and $\mathrm{H}_{2} \mathrm{O}_{2}$ oxidation of $\mathrm{Co}$ (II) in presence of the sodium salt of the relevant carboxylic acid and the required pyridine or substituted pyridine for successful preparation of the cluster complexes. This makes our procedure quite general for the synthesis of cubane-like tetrameric cobalt(III) complexes of the type $\mathrm{Co}_{4} \mathrm{O}_{4}\left(\mathrm{O}_{2} \mathrm{CR}\right)_{4} \mathrm{~L}_{4}$. The significant aspect of our work is that, unlike in reported procedures, ${ }^{14,15}$ complexes of other nuclearities are not found to occur in the isolated products. Also, while using a dichloromethane extract of the olive green products during work-up procedure for isolating the complexes in improved yields, the complexes were invariably found to be identical to the complex species present in the precipitated products obtained directly from the reaction mixtures. The vacuum-dried samples obtained via $\mathrm{CH}_{2} \mathrm{Cl}_{2}$ extraction correspond to the general formula $\mathrm{Co}_{4} \mathrm{O}_{4}\left(\mathrm{O}_{2} \mathrm{CR}\right)_{4} \mathrm{~L}_{4}$ as indicated by $\mathrm{C}, \mathrm{H}, \mathrm{N}$ and $\mathrm{Co}$ analyses.

The neutral tetrameric complexes of the type $\mathrm{Co}_{4} \mathrm{O}_{4}\left(\mathrm{O}_{2} \mathrm{CR}\right)_{4} \mathrm{~L}_{4}$ are soluble in common organic solvents to varying degrees. While they readily dissolve in $\mathrm{CH}_{2} \mathrm{Cl}_{2}$, their solubility is rather low in chloroform. They also have appreciable solubility in polar solvents such as $\mathrm{MeOH}$ and $\mathrm{MeCN}$. However, the complex $\mathrm{Co}_{4} \mathrm{O}_{4}\left(\mathrm{O}_{2} \mathrm{CMe}\right)_{4}(\mathrm{py})^{4}$ (1) dissolves in several solvents of widely differing polarity including water, DMF, DMSO, acetonitrile, ethanol, methanol acetone, diethyl ether and dichloromethane. The complexes with $\mathrm{R}=\mathrm{Me}$ generally show solubility in water. The integrity of the complexes in the dissolved state in various solvents is evidenced by their UV-visible and NMR spectra. These complexes are indefinitely stable in the solid state at room temperature.

\section{Crystal structure analysis}

The identity and structure of the olive green complexes of the type $\mathrm{Co}_{4} \mathrm{O}_{4}\left(\mathrm{O}_{2} \mathrm{CR}\right)_{4} \mathrm{~L}_{4}$ have been established by single crystal $\mathrm{X}$-ray diffraction. The crystal structure analysis of the compounds has proven to be an important part of our work due to several reasons. The first compound of the series was isolated in the form of rod-like crystals from the preparative reaction mixture involving $\mathrm{R}=\mathrm{Me}$ and $\mathrm{L}=$ py. Although single crystal X-ray diffraction data collected at room temperature was helpful in determining the identity of the complex species as $\mathrm{Co}_{4} \mathrm{O}_{4}\left(\mathrm{O}_{2} \mathrm{CMe}\right)_{4}(\mathrm{py})^{4}(\mathbf{1})$, the least squares refinement was far from satisfactory. ${ }^{18}$ While some of the carbon atoms belonging to the aromatic rings showed abnormal anisotropic thermal parameters, the residuals obtained were also very high $(\mathrm{R} \sim 0.22)$ because some electron density peaks could not be included in structure refinement. Using intensity data obtained at $-100^{\circ} \mathrm{C}$ it was possible to establish its composition as $1 \cdot 0.5 \mathrm{NaNO}_{3} \cdot 8 \mathrm{H}_{2} \mathrm{O} .{ }^{10}$ Presence of $\mathrm{NaNO}_{3}$ as a co-crystallizing salt in the crystals also helped us in rationalizing the observed electrical conductivity of solutions of the crystals in water and methanol. The same tetrameric complex was also obtained as dark olive-green crystals of composition $\mathbf{1} \cdot \mathrm{NaClO}_{4} \cdot 3.5 \mathrm{H}_{2} \mathrm{O}$ from the concentrated reaction mixture to which aqueous $\mathrm{NaClO}_{4}$ was added. ${ }^{9}$

The complex $\mathrm{Co}_{4} \mathrm{O}_{4}\left(\mathrm{O}_{2} \mathrm{CMe}\right)_{4}(\mathrm{py})^{4}$ (figure 1) consists of four each of $\mathrm{Co}^{3+}$ and $\mathrm{O}^{2-}$ ions occurring at alternate corners of a cube to form a $\left[\mathrm{Co}_{4} \mathrm{O}_{4}\right]^{4+}$ core with acetato ligands bridging the $\mathrm{Co}^{3+}$ ions along four face diagonals of the $\mathrm{Co}_{4} \mathrm{O}_{4}$ cube. On the other hand, the four Co atoms form an approximate tetrahedron with Co...Co separations of $\sim 2.75 \AA$. Pyridine ligands occupy the most outlying sites on the octahedral $\mathrm{Co}$ (III) centres. Inspection of the structural parameters leads to the conclusion that for the Co atoms, the $\mathrm{Co}-\mathrm{O}$ (oxide) and $\mathrm{Co}-\mathrm{O}$ (carboxylate) bond lengths are in the fairly narrow ranges of 1.860(3)1.876(3) and 1.948(3)-1.962(3) A, respectively. These

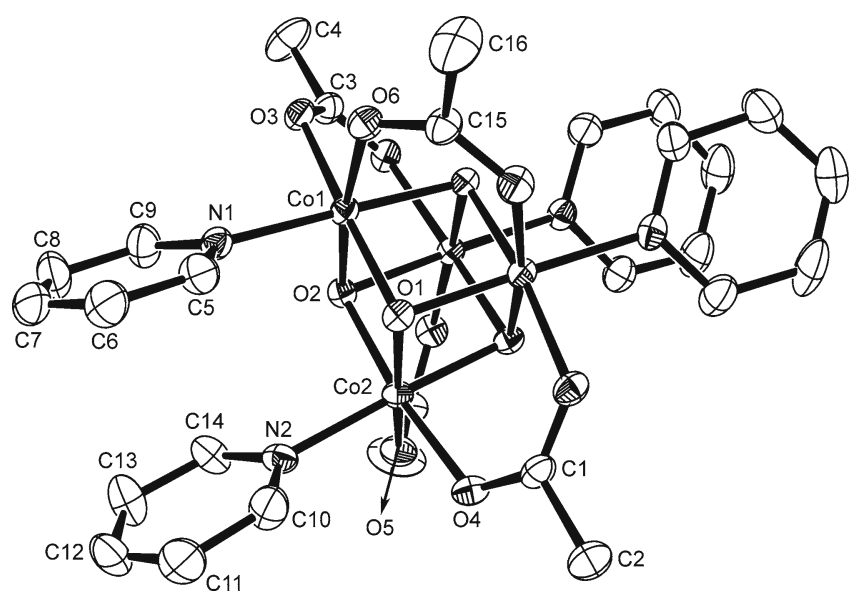

Figure 1. Molecular structure of $\left[\mathrm{Co}_{4} \mathrm{O}_{4}\left(\mathrm{O}_{2} \mathrm{CMe}\right)_{4}(\mathrm{py})^{4}\right]$ (1) in $\mathbf{1} \cdot \mathrm{NaClO}_{4} \cdot 3.5 \mathrm{H}_{2} \mathrm{O}$. Hydrogen atoms are omitted for clarity. 
values are consistent with a low spin configuration of $\mathrm{Co}(\mathrm{III})$. The average $\mathrm{Co}-\mathrm{N}$ distance is of the order of $1.96 \AA$. Two types Co...Co distances, close to (i) $2.82 \AA$ when Co...Co is bridged by two oxo-ligands only, and (ii) $2.70 \AA$ when bridged by two oxo-ligands and a bidentate carboxylato ligand, are observed. The bond parameters for the cubane-like $\left[\mathrm{Co}_{4}(\mu-\mathrm{O})_{4}\right]^{4+}$ core in all compounds studied by X-ray diffraction method are similar.

In the crystal structure of $\mathbf{1} \cdot \mathrm{NaClO}_{4} \cdot 3.5 \mathrm{H}_{2} \mathrm{O}$ the $\mathrm{Na}^{+}$ ions are found to bridge the cubane-like complexes to form zigzag chains that run along the crystallographic $a$ and $b$ directions. The two crystallographically distinct chains are related by $\overline{4}$ symmetry in the crystal lattice. Each sodium atom is in an approximately octahedral environment surrounded by six oxygen atoms, four from two carboxyl groups and the other two being contributed by two $\mathrm{H}_{2} \mathrm{O}$ molecules of crystallization (figure 2). ${ }^{9}$

In the crystal structure of $1 \cdot 0 \cdot 5 \mathrm{NaNO}_{3} \cdot 8 \mathrm{H}_{2} \mathrm{O}^{13}$ two molecules of the tetramer $\left[\mathrm{Co}_{4}\left(\mu_{3}-\mathrm{O}\right)_{4}(\mu-\right.$ $\left.\left.\mathrm{O}_{2} \mathrm{CMe}\right)_{4}(\mathrm{py})_{4}\right]$ along with one formula unit of $\mathrm{NaNO}_{3}$ and sixteen $\mathrm{H}_{2} \mathrm{O}$ molecules are found to constitute the asymmetric unit of the triclinic unit cell. Thermogravimetric studies corroborate the number of water molecules found from crystal structure analysis. ${ }^{10}$ The observed weight loss of $11.4 \%$ matches very well with the calculated weight loss of $11.5 \%$ for the chemical formula given by crystal structure analysis. Presence of co-crystallizing solvent molecules in crystals of the cubane clusters has been noted by us in other compounds such as $\mathrm{Co}_{4} \mathrm{O}_{4}\left(\mathrm{O}_{2} \mathrm{CMe}\right)_{4}(4-\mathrm{Mepy})_{4} \cdot 3 \mathrm{H}_{2} \mathrm{O},{ }^{9}$ $\mathrm{Co}_{4} \mathrm{O}_{4}\left(\mathrm{O}_{2} \mathrm{CC}_{6} \mathrm{H}_{5}\right)_{4}(\text { py })_{4} \cdot 6 \mathrm{MeOH} \cdot 0.5 \mathrm{H}_{2} \mathrm{O}^{8}$ and $\mathrm{Co}_{4} \mathrm{O}_{4}$ $\left(\mathrm{O}_{2} \mathrm{CC}_{6} \mathrm{H}_{5}\right)_{4}(4-\mathrm{Mepy})_{4} \cdot 3.5 \mathrm{MeOH} \cdot 5 \mathrm{H}_{2} \mathrm{O}^{8}$ as well. Crystal structure analysis of the last two compounds show that the cubanes having aryl carboxylates also present metrically similar $\left[\mathrm{Co}_{4}\left(\mu_{3}-\mathrm{O}\right)_{4}\right]^{4+}$ cores (figure 3). It is also worth noting that despite the presence of a number of hydrogen bonds forming via the involvement of the solvent molecules, crystals of $\mathrm{Co}_{4} \mathrm{O}_{4}\left(\mathrm{O}_{2} \mathrm{CC}_{6} \mathrm{H}_{5}\right)_{4}(\text { py })_{4} \cdot 6 \mathrm{MeOH} \cdot 0.5 \mathrm{H}_{2} \mathrm{O}$ are not stable at room temperature and as a result, the crystal had to be inserted into a Lindemann capillary containing mother liquor during intensity data collection. On the other hand, crystals obtained from less polar media were found to lose crystallinity in several cases.

It is seen from the above results that the cubane-like $\left[\mathrm{Co}_{4} \mathrm{O}_{4}\right]^{4+}$ core present in the complexes prepared by us is similar to those present in the related compounds which were reported earlier. ${ }^{14,15}$ Important structural parameters of cubane tetramers of $\mathrm{Co}(\mathrm{III})$ are compared in table 1. It is observed that the peripheral ligands have only a minor influence on the geometry of the tetrameric $\mathrm{Co}(\mathrm{III})$-oxo core present in the complexes. The $\left[\mathrm{Co}_{4}\left(\mu_{3}-\mathrm{O}\right)_{4}\right]^{4+}$ cuboid allows for two kinds of shortened Co...Co separations of $c a .2 .8 \AA$ and $c a .2 .7 \AA$. Although these $\mathrm{Co}^{3+} \ldots \mathrm{Co}^{3+}$ distances are fairly long for direct $\mathrm{Co}-\mathrm{Co}$ bond formation, the

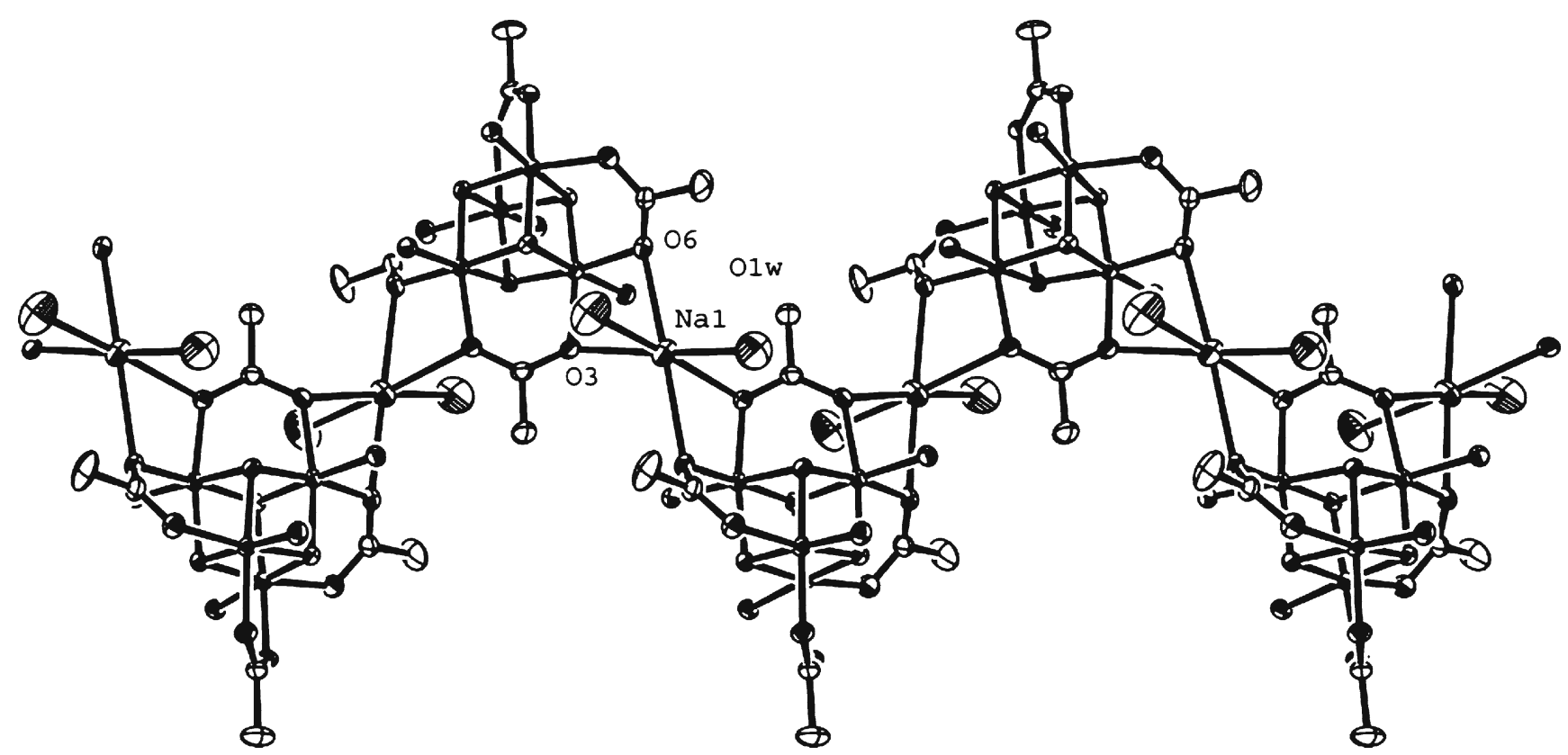

Figure 2. Sodium-bridged zigzag supramolecular chain of $\mathbf{1}$ in the crystal structure of $\mathbf{1} \cdot \mathrm{NaClO}_{4} \cdot 3.5 \mathrm{H}_{2} \mathrm{O}$. $\mathrm{Hydrogen}$ atoms and uncoordinated water molecules are omitted for clarity. 
(a)

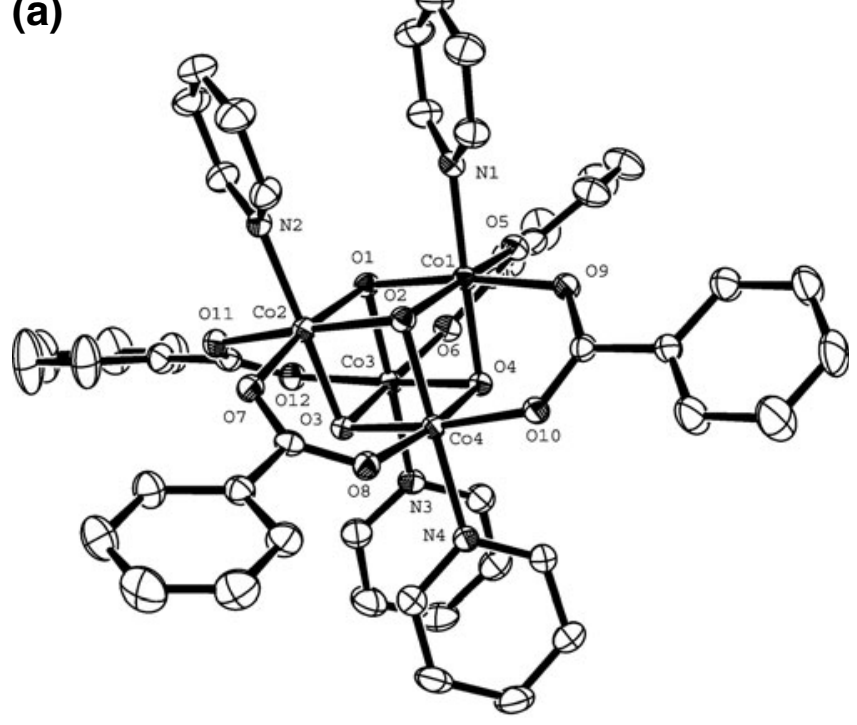

(b)

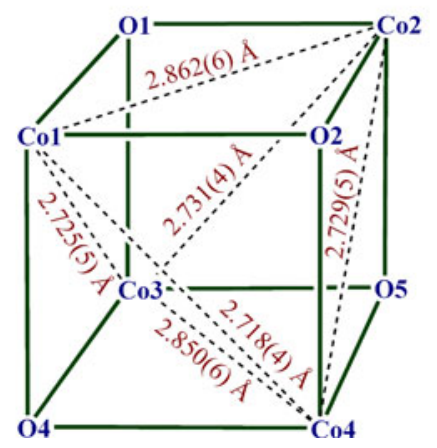

Figure 3. (a) Molecular structure of the cubane cluster and (b) Co $\cdots$ Co separations for the $\mathrm{Co}_{4}$ tetrahedron in the inner $\left[\mathrm{Co}_{4}\left(\mu_{3}-\mathrm{O}\right)_{4}\right]^{4+}$ core in $\mathrm{Co}_{4} \mathrm{O}_{4}\left(\mathrm{O}_{2} \mathrm{CC}_{6} \mathrm{H}_{5}\right)_{4}(\mathrm{py})_{4} \cdot 6 \mathrm{MeOH} \cdot 0.5 \mathrm{H}_{2} \mathrm{O}$.

existence of an approximately tetrahedral assembly of four cobalt atoms in each compound is notable (figure 3(b)). Each $\mathrm{O}^{2-}$ ligand may then be considered to cap a triangular face of the $\mathrm{Co}_{4}$ tetrahedron.

\section{Physicochemical properties of $\mathrm{Co}_{4} \mathrm{O}_{4}\left(\mathrm{O}_{2} \mathrm{CR}\right)_{4} \mathrm{~L}_{4}$}

It has been described above that a number of cubanelike complexes of general formula $\mathrm{Co}_{4} \mathrm{O}_{4}\left(\mathrm{O}_{2} \mathrm{CR}\right)_{4} \mathrm{~L}_{4}$ may be prepared by following the general proce dures developed by us. The complexes belonging to the series have been investigated by various spectroscopic and analytical techniques. Based on crystallographic results, it may be assumed that aided by short $\mathrm{Co}^{\mathrm{III}}-\mathrm{O}$ (oxide) distances and Co...Co separations, the tetranuclear core of the cubane complexes is quite robust. This may explain the preeminence of the molecular ion peaks in the ESI-MS spectra obtained for the compounds. A representative spectrum is shown as part of supplementary materials.

The ${ }^{1} \mathrm{H}$ NMR spectra of these complexes are characterized by sharp signals due to their diamagnetic nature. The cobalt(III) ions with a low-spin $\mathrm{d}^{6}$ electron configuration are expected to be diamagnetic, particularly in the presence of pyridine as a ligand. ${ }^{20}$ While the ${ }^{1} \mathrm{H}$ NMR spectrum of $\mathrm{Co}_{4} \mathrm{O}_{4}\left(\mathrm{O}_{2} \mathrm{CC}_{6} \mathrm{H}_{4}-4-\mathrm{OMe}\right)_{4}(4-$ Mepy $)_{4}$. is given as supplementary material, the ${ }^{13} \mathrm{C}$ NMR spectrum of $\mathrm{Co}_{4} \mathrm{O}_{4}\left(\mathrm{O}_{2} \mathrm{CMe}\right)_{4}(\mathrm{py})^{4}$ is shown in figure 4 . The simplicity of the spectra clearly indicates the presence of only one type of environment for pyridyl as well as carboxylato ligands and thus it is consistent with a virtual $\mathrm{T}_{\mathrm{d}}$ symmetry of the molecule in solution. It suggests the retention of molecular integrity on dissolution. For all other complexes in the series we have obtained the proton NMR spectra to establish that in all cases we isolated pure cobalt(III)-oxo cubane clusters (selected spectral data are given as part of supplementary materials, see www.ias.ac.in/chemsci). The NMR spectra thus provide conclusive evidence for the bulk purity of the product. At the same time, the spectra also suggest that the oligonuclear complexes remain intact in the solution phase as well.

UV-visible spectra of the tetranuclear cobalt(III)oxo clusters have been studied in the solution phase. The spectral data for the complex $\mathrm{Co}_{4} \mathrm{O}_{4}\left(\mathrm{O}_{2} \mathrm{CMe}\right)_{4}(\mathrm{py})^{4}$ obtained using several common solvents are presented in table 2. The electronic spectra for this compound in $\mathrm{CH}_{2} \mathrm{Cl}_{2}$ and $\mathrm{H}_{2} \mathrm{O}$ at three different concentrations are shown in figure 5. As can be seen from the data, the spectra are slightly solvent-as well as concentrationdependent. The spectral bands found in $\mathrm{MeOH}$ occur at $617 \mathrm{~nm} \quad\left(\varepsilon=360 \mathrm{M}^{-1} \mathrm{~cm}^{-1}\right), 330 \mathrm{~nm} \quad(\varepsilon=$ $\left.5900 \mathrm{M}^{-1} \mathrm{~cm}^{-1}\right)$ and $246 \mathrm{~nm}\left(\varepsilon=21,900 \mathrm{M}^{-1} \mathrm{~cm}^{-1}\right)$. The lowest energy band at $617 \mathrm{~nm}$ can be assigned to the $\mathrm{d}-\mathrm{d}$ transition involving either ${ }^{1} \mathrm{~A}_{1} \rightarrow{ }^{1} \mathrm{~T}_{1}$ or ${ }^{1} \mathrm{~A}_{1} \rightarrow{ }^{1} \mathrm{~T}_{2}$ for the approximately octahedral low-spin $\mathrm{d}^{6}$ $\mathrm{Co}$ (III) centers. As judged from the observed intensities, the other two bands are attributable to ligand to metal charge transfer transitions (LMCT). While the first LMCT band at $330 \mathrm{~nm}$ is likely to be due to a transition involving the $\mu_{3}-\mathrm{O}-\mathrm{Co}(\mathrm{III})$ moiety present in the complex, the latter occurring at $246 \mathrm{~nm}$ most probably involves a transition between a molecular orbital from the carboxylato ligands and a vacant cobalt(III) $\mathrm{e}_{\mathrm{g}}$ * orbital.

As noted above, the spectral traces depend to some extent on the solvent and concentration used. For example, the above complex shows bands in the visible region in $\mathrm{CH}_{2} \mathrm{Cl}_{2}$ and $\mathrm{MeCN}$ at 638 and $650 \mathrm{~nm}$ respectively indicating a significant shift in band 
Table 1. Average interatomic bond distances $[\AA]$ and angles $\left[{ }^{\circ}\right]$ for tetranuclear complexes having $\left[\left(\mathrm{Co}^{\mathrm{III}}\right)_{4}\left(\mu_{3}-\mathrm{O}\right)_{4}\right]^{4+}$ core.

\begin{tabular}{|c|c|c|c|c|c|c|c|c|}
\hline Compound $^{\mathrm{a}}$ & $\mathrm{Co}-\mathrm{N}_{\text {arom. }}$ & $\mathrm{Co}-\left(\mu_{3}-\mathrm{O}\right)$ & $\mathrm{Co}-\mathrm{O}_{\text {carbox. }}$ & Co... Co ${ }^{b}$ & $\mathrm{Co} \ldots \mathrm{Co}^{\mathrm{c}}$ & $\mathrm{O}-\mathrm{Co}-\mathrm{O}^{\mathrm{d}}$ & $\mathrm{Co}-\mathrm{O}-\mathrm{Co}^{\mathrm{d}}$ & Reference \\
\hline $\begin{array}{l}{\left[\mathrm{Co}_{4} \mathrm{O}_{4}\left(\mathrm{O}_{2} \mathrm{CC}_{6} \mathrm{H}_{4}-p-\mathrm{Me}\right)_{2}(\mathrm{bpy})_{4}\right]} \\
\quad\left(\mathrm{ClO}_{4}\right)_{2} \cdot 2 \mathrm{MeCN}\end{array}$ & 1.939 & 1.882 & 1.959 & 2.852 & 2.665 & - & - & {$\left[{ }^{14}\right]$} \\
\hline $\mathrm{Co}_{4} \mathrm{O}_{4}\left(\mathrm{O}_{2} \mathrm{CMe}\right)_{4}(\mathrm{py})^{4} \cdot 5 \mathrm{CHCl}_{3}$ & 1.973 & 1.865 & 1.962 & 2.818 & 2.683 & 85.9 & 93.6 & {$\left[{ }^{15}\right]$} \\
\hline $\mathrm{Co}_{4}(\mathrm{pg})_{4} \mathrm{O}_{4}$ & 1.960 & 1.887 & 1.945 & 2.78 & - & 83.9 & 95.8 & {$\left[{ }^{19}\right]$} \\
\hline $\begin{array}{c}\mathrm{Co}_{4} \mathrm{O}_{4}\left(\mathrm{O}_{2} \mathrm{CMe}_{4}(\mathrm{py})^{4}\right. \\
\cdot 0.5 \mathrm{NaNO}_{3} \cdot 8 \mathrm{H}_{2} \mathrm{O}\end{array}$ & 1.962 & 1.865 & 1.953 & 2.815 & 2.702 & 85.0 & 94.6 & {$\left[{ }^{10}\right]$} \\
\hline $\begin{array}{l}\mathrm{Co}_{4} \mathrm{O}_{4}\left(\mathrm{O}_{2} \mathrm{CMe}\right)_{4}(\mathrm{py})^{4} \\
\cdot \mathrm{NaClO}_{4} \cdot 3.5 \mathrm{H}_{2} \mathrm{O}\end{array}$ & 1.968 & 1.870 & 1.956 & 2.823 & 2.709 & 84.4 & 95.4 & {$\left[{ }^{9}\right]$} \\
\hline $\mathrm{Co}_{4} \mathrm{O}_{4}\left(\mathrm{O}_{2} \mathrm{CMe}\right)_{4}(4-\mathrm{Mepy})_{4} \cdot 3 \mathrm{H}_{2} \mathrm{O}$ & 1.959 & 1.868 & 1.963 & 2.816 & 2.701 & 85.3 & 94.3 & {$\left[{ }^{9}\right]$} \\
\hline $\begin{array}{l}\mathrm{Co}_{4} \mathrm{O}_{4}\left(\mathrm{O}_{2} \mathrm{CC}_{6} \mathrm{H}_{5}\right)_{4}(\text { py })_{4} \cdot 6 \mathrm{MeOH} \\
\cdot 0.5 \mathrm{H}_{2} \mathrm{O}\end{array}$ & 1.968 & 1.883 & 1.967 & 2.856 & 2.725 & 85.4 & 94.69 & {$\left[{ }^{8}\right]$} \\
\hline $\begin{array}{l}\mathrm{Co}_{4} \mathrm{O}_{4}\left(\mathrm{O}_{2} \mathrm{CC}_{6} \mathrm{H}_{5}\right)_{4}(4-\mathrm{Mepy})_{4} \\
3.5 \mathrm{MeOH} \cdot 5 \mathrm{H}_{2} \mathrm{O}\end{array}$ & 1.955 & 1.866 & 1.951 & 2.826 & 2.708 & 84.21 & 95.15 & {$\left[{ }^{8}\right]$} \\
\hline
\end{tabular}

${ }^{\mathrm{a}} \mathrm{Hpg}=N$-(2-pyridylmethyl)glycine; ${ }^{\mathrm{b}}$ bridged by two oxo ligands only; ${ }^{\mathrm{c}}$ bridged by two oxo ligands and a bidentate carboxylato ligand; ${ }^{\mathrm{d}}$ only oxygen atoms of the $\mathrm{Co}_{4} \mathrm{O}_{4}$ core considered

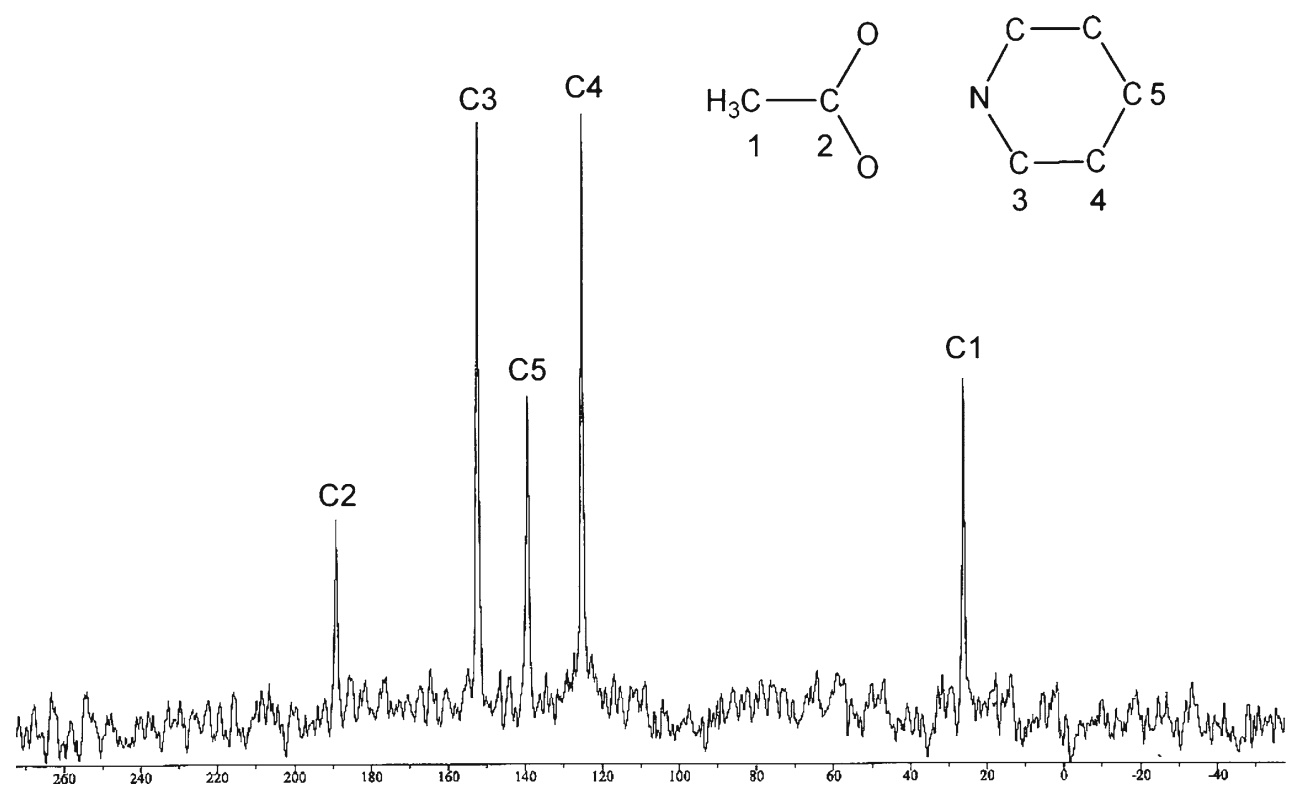

Figure 4. ${ }^{13} \mathrm{C} \mathrm{NMR}$ spectrum of $\mathrm{Co}_{4} \mathrm{O}_{4}\left(\mathrm{O}_{2} \mathrm{CMe}\right)_{4}(\mathrm{py})^{4}$ in $\mathrm{D}_{2} \mathrm{O}$.

Table 2. Electronic spectral data on $\mathrm{Co}_{4} \mathrm{O}_{4}\left(\mathrm{O}_{2} \mathrm{CMe}\right)_{4}(\mathrm{py})^{4}$ in various solvents.

\begin{tabular}{lccc}
\hline \multirow{2}{*}{ Solvent } & \multicolumn{3}{c}{$\lambda_{\max }, \mathrm{nm}\left(\varepsilon, \mathrm{M}^{-1} \mathrm{~cm}^{-1}\right)$} \\
\cline { 2 - 4 } & ${ }^{1} \mathrm{~A}_{1} \rightarrow{ }^{1} \mathrm{~T}_{1}$ & LMCT $\left(\mu_{3}\right.$-oxo-bridge $)$ & LMCT \\
\hline $\mathrm{MeOH}$ & $617(360)$ & $330(5,900)$ & $246(21,900)$ \\
$\mathrm{CH}_{2} \mathrm{Cl}{ }_{2}$ & $638(\mathrm{sh})$ & $362(7,428)$ & $227(26,537)$ \\
$\mathrm{MeCN}$ & $650(330)$ & $355(7,149)$ & - \\
$\mathrm{H}_{2} \mathrm{O}$ & $618(388)$ & $354(4,742)$ & $257(42,879)$ \\
\hline
\end{tabular}


(a)

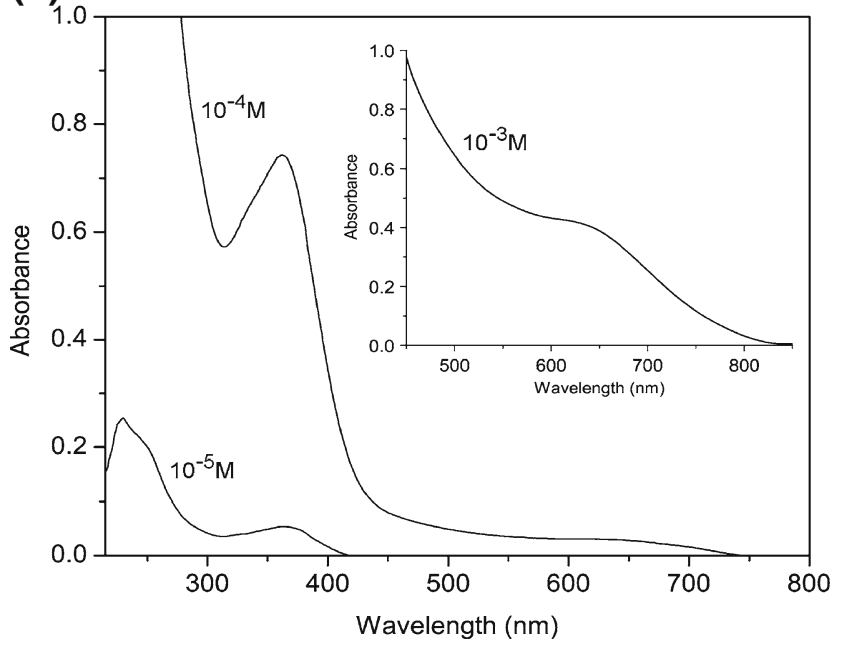

Figure 5. UV-visible spectra of $\mathrm{Co}_{4} \mathrm{O}_{4}\left(\mathrm{O}_{2} \mathrm{CMe}\right)_{4}(\mathrm{py})^{4}$ in $10^{-3}, 10^{-4}$ and $10^{-5} \mathrm{M}$ solutions.

positions. Again, the $362 \mathrm{~nm}\left(\varepsilon=7,428 \mathrm{M}^{-1} \mathrm{~cm}^{-1}\right)$ band in $\mathrm{CH}_{2} \mathrm{Cl}_{2}$ becomes blue-shifted to $355 \mathrm{~nm}$ $\left(\varepsilon=7,149 \mathrm{M}^{-1} \mathrm{~cm}^{-1}\right)$ in $\mathrm{MeCN}$. The characteristic visible peak due to the $\mathrm{d}-\mathrm{d}$ transition remains similar in shape, although the band position undergoes considerable shift from the values found in $\mathrm{CH}_{2} \mathrm{Cl}_{2}$ and $\mathrm{MeCN}$. On the other hand, the visible band at $618 \mathrm{~nm}$ $\left(\varepsilon=388 \mathrm{M}^{-1} \mathrm{~cm}^{-1}\right)$ observed in $\mathrm{H}_{2} \mathrm{O}$ occurs almost at the same energy with the band observed in $\mathrm{MeOH}$ $(617 \mathrm{~nm})$, although the lower energy LMCT bands in these two solvents appear at widely separated wavelengths (354 nm for $\mathrm{H}_{2} \mathrm{O}$ and $330 \mathrm{~nm}$ for $\mathrm{MeOH}$ ). From these results, it may be said that the $\left[\mathrm{Co}_{4} \mathrm{O}_{4}\right]^{4+}$ core of the complex undergoes deformation to varying degrees in different solvents. At the same time, it is not possible to rule out the possibility of $\mathrm{H}_{2} \mathrm{O}$ and $\mathrm{MeOH}$ entering into hydrogen bonding interactions with the oxo-ligands so as to change the shape of the $\mathrm{Co}_{4} \mathrm{O}_{4}$ cube further. This could perhaps explain why the $d-d$ band positions in these two solvents appear at nearly the same energies. The highest energy LMCT transition is not observed in $\mathrm{MeCN}$ for as yet unknown reasons.

The above spectral results are typical of complexes of the type $\mathrm{Co}_{4} \mathrm{O}_{4}\left(\mathrm{O}_{2} \mathrm{CR}\right)_{4} \mathrm{~L}_{4}$; spectra of several other complexes in the series have been recorded (please see supplementary materials for spectral data on other related complexes www.ias.ac.in/chemsci).

The mid-IR spectra recorded for the cubane-like cobalt(III) complexes are also informative. It is possible to identify bands due to the pyridyl as well as carboxylato ligands present in the complexes. Also, the (b)

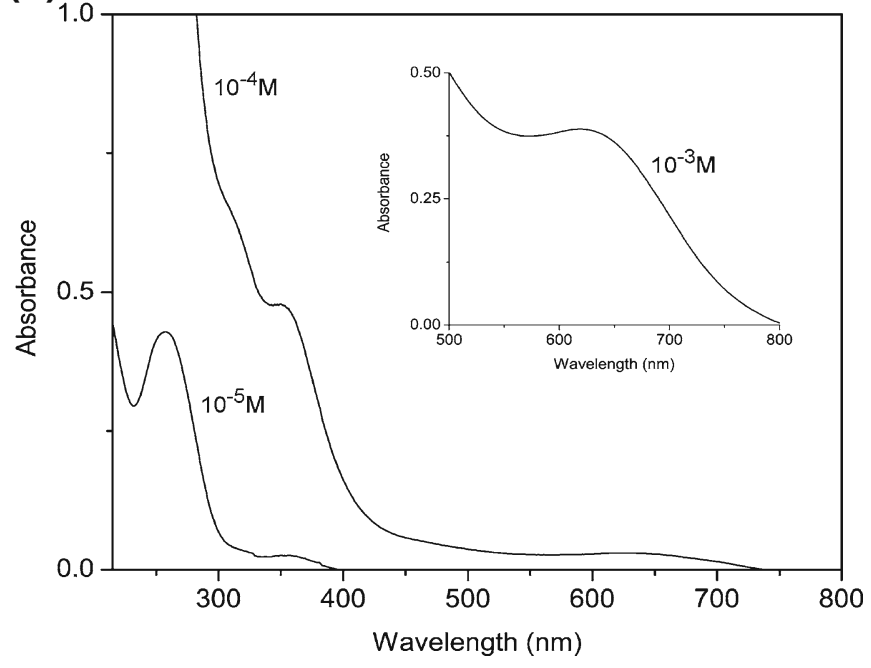

(a) $\mathrm{CH}_{2} \mathrm{Cl}_{2}$ and (b) $\mathrm{H}_{2} \mathrm{O}$ obtained through measurements on presence of the triply bridging oxide ions in these complexes is evidenced by the appearance of a moderate intensity band at $\sim 635 \mathrm{~cm}^{-1}$. A four-band pattern observed at $\sim 760, \sim 695, \sim 635$ and $\sim 580 \mathrm{~cm}^{-1}$ for the cubane complexes (please see supplementary materials for examples) is a characteristic feature of the IR spectra of $\mathrm{Co}_{4} \mathrm{O}_{4}\left(\mathrm{O}_{2} \mathrm{CR}\right)_{4} \mathrm{~L}_{4}$.

The redox behaviour of the cubane clusters of cobalt(III) has been studied by cyclic voltammetry.

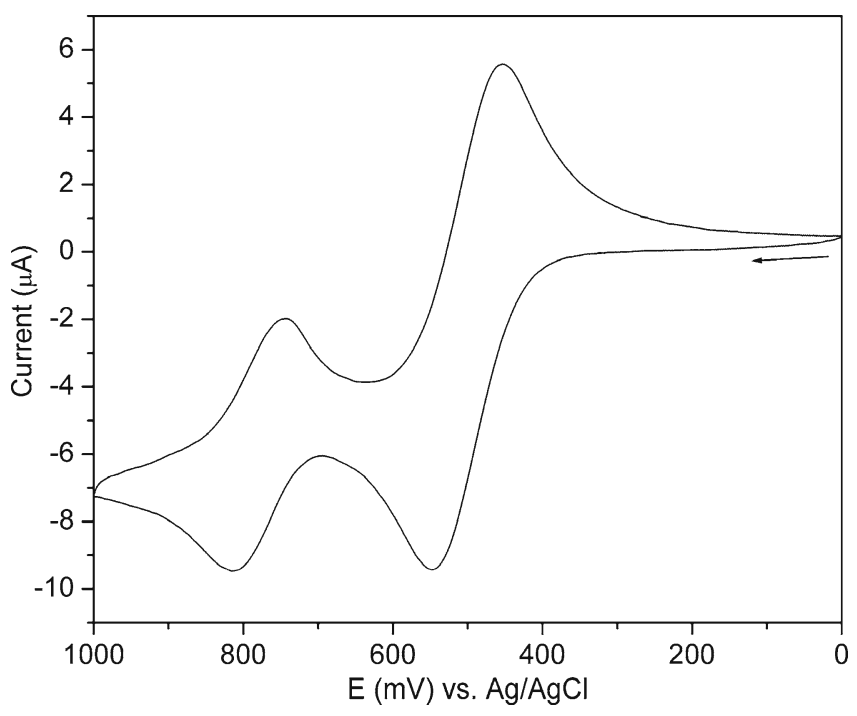

Figure 6. Cyclic voltammogram at $20 \mathrm{mVs}^{-1}$ on Pt electrode $(\mathrm{Ag} / \mathrm{AgCl}$ reference electrode $)$ of $\mathrm{Co}_{4}\left(\mu_{3}-\mathrm{O}\right)_{4}(\mu-$ $\left.\mathrm{O}_{2} \mathrm{CMe}\right)_{4}(\mathrm{py})_{4}$ in $\mathrm{MeCN}$ containing $0.2 \mathrm{M}$ TBAP and ferrocene as an internal standard. $\mathrm{E}_{1 / 2}\left(\mathrm{Co}^{3+} / \mathrm{Co}^{4+}\right)=0.73 \mathrm{~V}$, $\Delta \mathrm{E}_{p}=66 \mathrm{mV}$. 
Table 3. $\mathrm{CV}^{\mathrm{a}}$ and $\mathrm{DPV}^{\mathrm{b}}$ data for a few $\mathrm{Co}_{4} \mathrm{O}_{4}\left(\mathrm{O}_{2} \mathrm{CR}\right)_{4}(\mathrm{~L})_{4}$ complexes in $\mathrm{CH}_{2} \mathrm{Cl}_{2}-0.1 \mathrm{M}$ TBAP.

\begin{tabular}{lccc}
\hline \multirow{2}{*}{ Complex } & \multicolumn{2}{c}{$\mathrm{CV}$ data } & DPV data (V) \\
\cline { 2 - 4 } & $\mathrm{E}_{1 / 2}(\mathrm{~V})$ & $\Delta \mathrm{E}_{\mathrm{p}}(\mathrm{mV})$ & \\
\hline $\mathrm{Co}_{4}\left(\mu_{3}-\mathrm{O}\right)_{4}\left(\mu-\mathrm{O}_{2} \mathrm{CMe}\right)_{4}(\mathrm{py})_{4}$ & 0.75 & 170 & 0.77 \\
$\mathrm{Co}_{4}\left(\mu_{3}-\mathrm{O}\right)_{4}\left(\mu-\mathrm{O}_{2} \mathrm{CMe}\right)_{4}(4-\mathrm{Mepy})_{4}$ & 0.71 & 138 & 0.73 \\
$\mathrm{Co}_{4}\left(\mu_{3}-\mathrm{O}\right)_{4}\left(\mu-\mathrm{O}_{2} \mathrm{CMe}\right)_{4}(4-\mathrm{Etpy})_{4}$ & 0.72 & 140 & 0.74 \\
$\mathrm{Co}_{4}\left(\mu_{3}-\mathrm{O}\right)_{4}\left(\mu-\mathrm{O}_{2} \mathrm{CMe}\right)_{4}(4-\mathrm{CNpy})_{4}$ & 1.0 & 128 & 1.02 \\
\hline
\end{tabular}

${ }^{\mathrm{a}} \mathrm{Scan}$ rate, $20 \mathrm{mVs}^{-1}$, ${ }^{\mathrm{b}}$ scan rate, $5 \mathrm{mVs}^{-1}$, working electrode, $\mathrm{Pt}$; reference electrode, $\mathrm{Ag} / \mathrm{AgCl}$

$$
\left[\mathrm{Co}_{4}{ }^{\prime \prime \prime} \mathrm{O}_{4}\left(\mu_{3}-\mathrm{O}\right)_{4}\left(\mu-\mathrm{O}_{2} \mathrm{CMe}\right)_{4}(\mathrm{~L})_{4}\right] \stackrel{-\mathrm{e}}{\stackrel{+\mathrm{e}}{\longrightarrow}}\left[\mathrm{Co}_{3}{ }^{\mathrm{III}} \mathrm{Co}^{\mathrm{IV}} \mathrm{O}_{4}\left(\mu_{3}-\mathrm{O}\right)_{4}\left(\mu-\mathrm{O}_{2} \mathrm{CMe}\right)_{4}(\mathrm{~L})_{4}\right]^{+}
$$

Scheme 2. Redox couple involved in the one electron oxidation of $\mathrm{Co}_{4} \mathrm{O}_{4}\left(\mathrm{O}_{2} \mathrm{CMe}\right)_{4} \mathrm{~L}_{4}$.

Figure 6 shows the $\mathrm{CV}$ recorded for a $10^{-3} \mathrm{M}$ solution of complex $\mathrm{Co}_{4}\left(\mu_{3}-\mathrm{O}\right)_{4}\left(\mu-\mathrm{O}_{2} \mathrm{CMe}\right)_{4}(\mathrm{py})_{4}$ in $\mathrm{MeCN}$ containing $0.2 \mathrm{M}$ TBAP as the supporting electrolyte (scan rate $=10 \mathrm{mVs}^{-1}$ ) and ferrocene as the internal standard using platinum electrode. The electrochemical studies reveal a reversible oxidation at $0.73 \mathrm{~V}$ for this particular complex. Other complexes also show similar $\mathrm{E}_{1 / 2}$ values, some of which are listed in table 3 . However, change of solvent from $\mathrm{MeCN}$ to $\mathrm{CH}_{2} \mathrm{Cl}_{2}$ makes the electrochemical process quasireversible. It is imperative that the tetrameric $\left[\mathrm{Co}_{4}\left(\mu_{3}-\mathrm{O}\right)_{4}\right]^{4+}$ core undergoes a one-electron oxidation to $\left[\mathrm{Co}_{4}\left(\mu_{3}-\mathrm{O}\right)_{4}\right]^{5+}$ to form a mixed valence tetranuclear complex that contains three $\mathrm{Co}^{\mathrm{III}}$ and one $\mathrm{Co}^{\mathrm{IV}}$ ions, as had been observed for a related complex. Such a favourable electrochemical redox potential for the cubane complexes suggests their suitability as redox catalysts in the oxidation of organic substrates.

The stoichiometry of electron transfer can be determined from the peak current measurements using ferrocene in equimolar concentration as an internal standard. It is found that the ratio of observed peak currents for ferrocene and $\mathrm{Co}_{4} \mathrm{O}_{4}\left(\mu-\mathrm{O}_{2} \mathrm{CMe}\right)_{4}(\mathrm{py})_{4}$ is $\sim 4$ (figure 6). This suggests that only one $\mathrm{Co}^{\mathrm{III}}$ centre per ' $\left(\mathrm{Co}{ }^{\mathrm{III}}\right)_{4} \mathrm{O}_{4}$ ' cluster undergoes oxidation. Thus the electron transfer process involves a one electron oxidation of the cubane core from $\left[\left(\mathrm{Co}^{\mathrm{III}}\right)_{4}\left(\mu_{3}-\mathrm{O}\right)_{4}\right]^{4+}$ to $\left[\left(\mathrm{Co}^{\mathrm{III}}\right)_{3} \mathrm{Co}^{\mathrm{IV}}\left(\mu_{3}-\mathrm{O}\right)_{4}\right]^{5+}$ (scheme 2). A literature report $^{21}$ on a structurally related complex $\left[\mathrm{Co}_{4}\left(\mu_{3^{-}}\right.\right.$ $\left.\mathrm{O})_{4}\left(\mu-\mathrm{O}_{2} \mathrm{CMe}\right)_{2}(\text { bpy })_{2}\right]^{2+}$ in $\mathrm{MeCN}$ revealed a similar oxidation process where the cubane core $\left[\mathrm{Co}_{4}\left(\mu_{3}\right.\right.$ O) $\left.)_{4}\right]^{4+}$ containing $4 \mathrm{Co}^{\mathrm{III}}$ was oxidized to a $3 \mathrm{Co}^{\mathrm{III}}, \mathrm{Co}^{\mathrm{IV}}$ form.
Several other cubane complexes of the type $\mathrm{Co}_{4} \mathrm{O}_{4}\left(\mathrm{O}_{2} \mathrm{CR}\right)_{4} \mathrm{~L}_{4}$ also have been studied by electrochemical methods and in all cases we observe very similar electrochemical behaviour. The observed $\mathrm{E}_{1 / 2}$ values may be correlated to Hammett constants for substituents on aromatic rings. ${ }^{8}$

\section{Catalytic behaviour in aerobic oxidation}

A few of the cubane-like cobalt(III) complexes described above have been found to catalyse the oxidation of some commercially important organic substrates. It is to be noted that the neutral tetrameric complexes display appreciable solubility in organic media at room temperature and hence they may be expected to serve as homogeneous catalysts or catalyst precursors in the redox transformation of organic compounds.

The complex $\mathrm{Co}_{4} \mathrm{O}_{4}\left(\mathrm{O}_{2} \mathrm{CMe}\right)_{4}(\mathrm{py})^{4}$ has been found to mediate the aerobic oxidation of neat ethylbenzene to form acetophenone in $\sim 69 \%$ yield. No additional solvent is required in this conversion that produces 1phenylethanol $(1 \%)$ as the only other minor product at the end of $22 \mathrm{~h}$ (scheme 3). An excellent 99\% selectivity for acetophenone has been achieved. As indicated by gas chromatographic studies, the conversion of ethylbenzene proceeds more or less linearly with time at the rate of $c a .5 \%$ per hour at $120^{\circ} \mathrm{C}$ for the first four hours and thereafter the rate of oxidation slows down a little, but the rise in conversion remains almost linear up to $22 \mathrm{~h}$ after which the amount of acetophenone levels off. Unlike in the cases of Co(II)-based processes where the metal needs to undergo oxidation to 


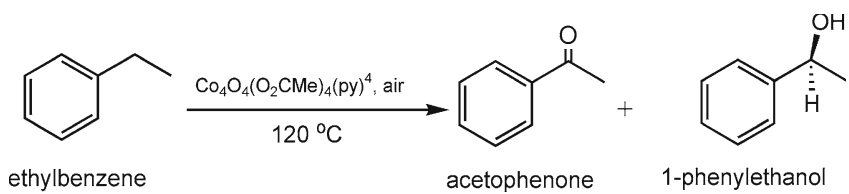

Scheme 3. Aerobic oxidation of ethylbenzene catalysed by $\mathrm{Co}_{4} \mathrm{O}_{4}\left(\mathrm{O}_{2} \mathrm{CMe}\right)_{4}(\mathrm{py})^{4}$.

Co(III) initially in a sluggish manner, ${ }^{22}$ no induction period is observed in the use of the present $\mathrm{Co}(\mathrm{III})$ based reaction. Product selectivities are also much better with our cubane complexes compared even to the $\mathrm{Co}$ (III) complexes which are reported ${ }^{23}$ to be highly active in the oxidation of ethylbenzene to acetophenone at $150^{\circ} \mathrm{C}$. The acetophenone productivity calculated for the present study is 2310 moles per mole of catalyst, while the turnover frequency calculated for the first four hours of the reaction is $212 \mathrm{~h}^{-1}$. Our results obtained under homogeneous conditions by making use of the cobalt(III) cubane clusters also compare well with the highly active heterogeneous catalyst, also based on a Co(III)-oxo species. ${ }^{16}$

The cubane complexes has also been found to be useful in the autoxidation of $p$-xylene with air under atmospheric pressure and in absence of any co-catalysts or additives under solvent-free condition (scheme 4). During autoxidation of $p$-xylene with compressed air formation of solid product starts immediately. Due to the build-up of a large quantity of solid product the reaction needs to be stopped at the end of $7 \mathrm{~h}$. The isolated yields of $p$-toluic acid and terephthalic acid are found to be $\sim 25 \%$ and $\sim 1 \%$. The compound $\mathrm{Co}_{4} \mathrm{O}_{4}\left(\mathrm{O}_{2} \mathrm{CMe}\right)_{4}(4-$ $\mathrm{CNpy})_{4}$ is also active under moderate $\mathrm{O}_{2}$ pressure in aqueous medium. In this case also, $p$-toluic acid is the main product with only traces of terephthalic acid forming as the other product. ${ }^{12}$ Our results thus indicate that the cobalt(III)-oxo clusters may be active as catalysts for $p$-xylene oxidation in highly polar (water) as well as non-polar ( $p$-xylene) media. Further studies are however necessary to make these findings commercially

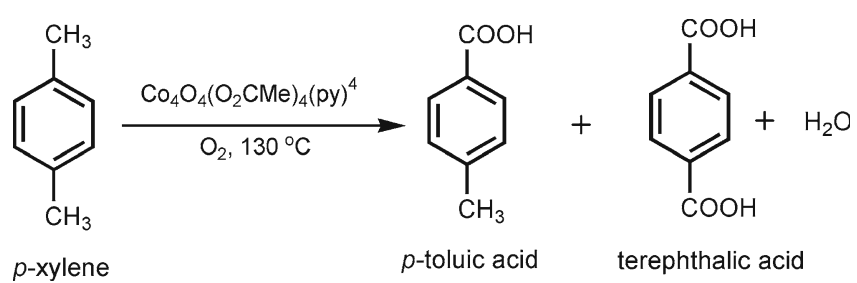

Scheme 4. Aerobic oxidation of $p$-xylene catalysed by $\mathrm{Co}_{4} \mathrm{O}_{4}\left(\mathrm{O}_{2} \mathrm{CMe}\right)_{4}(\mathrm{py})^{4}$. attractive. Suitable modification of reaction conditions as well as experimental set-up is expected to improve yields and selectivities of products in these catalysed oxidation processes. The survival of the cubane complexes through the course of the oxidation reactions also suggests that under appropriate conditions the reuse of the catalysts may be possible.

Typically cobalt-catalysed autoxidation of $p$-xylene in the liquid phase is carried out in acetic acid medium at very high temperature $\left(195-205^{\circ} \mathrm{C}\right)$ and pressure $(\sim 30$ bar $)$ in the presence of halide ion promoter that significantly changes the reaction kinetics of such processes. ${ }^{2,22}$ Since the oxidation of $\mathrm{Co}$ (II) to $\mathrm{Co}$ (III) is a slow process, use of promoters is necessary in cobalt(II)-catalysed processes to prevent a possible induction period during which no desired conversion takes place. The avoidance of induction period and polluting promoters, redundancy of solvents and the usability of water as a solvent in alkyl aromatic oxidation thus make these conversions quite friendly from an environmental point of view.

Oxidation of renewable feedstock to produce valueadded chemicals constitutes an important area of research. ${ }^{24}$ Transition metal based catalysts for such transformations are quite important. ${ }^{25}$ In the above context, oxidation of $\alpha$-pinene, which occurs widely in the plant kingdom, may be viewed as an important reaction because oxidation products of $\alpha$-pinene find use as the starting materials for fragrance, flavour and therapeutic agents including taxol. ${ }^{26}$ The tetrameric cubane-like complex $\left[\mathrm{Co}_{4} \mathrm{O}_{4}\left(\mathrm{O}_{2} \mathrm{CC}_{6} \mathrm{H}_{5}\right)_{4}(4-\mathrm{CNpy})_{4}\right]$ was examined as a catalyst for the homogeneous air oxidation of $\alpha$-pinene under atmospheric pressure (scheme 5) and found to favour the preferential formation of the epoxide product.

This reaction was carried out under homogeneous conditions at an elevated temperature using 1,4-dioxane as the solvent. ${ }^{13}$ The effect of reaction temperature was studied by taking $25 \mathrm{mg}(0.08 \mathrm{~mol} \%)$ of the catalyst and allowing the reaction to take place at $60^{\circ} \mathrm{C}, 80^{\circ} \mathrm{C}$ or $100^{\circ} \mathrm{C}$, respectively. By monitoring the progress of the reaction by GC it was found that an increase in the reaction temperature accelerates air oxidation of $\alpha$ pinene with the highest conversion of $66.8 \%$ being observed at $100^{\circ} \mathrm{C}$ after $24 \mathrm{~h}$. At all the three temperatures air oxidation commenced quickly with a preferential formation of $\alpha$-pinene oxide over other oxidation products.

In order to evaluate the optimum catalyst requirement in the air oxidation of $\alpha$-pinene, the catalyst concentration was varied between $0.01 \mathrm{~mol} \%$ to $0.5 \mathrm{~mol} \%$. 

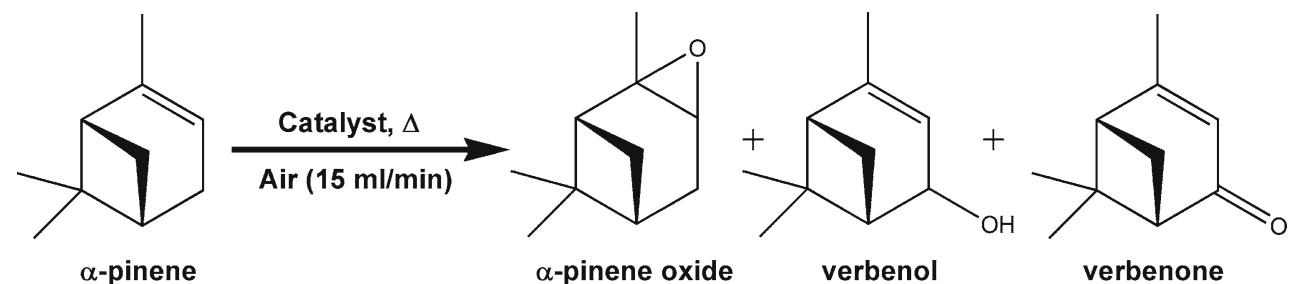

$\alpha-p i n e n e$ oxide

verbenol

verbenone

Scheme 5. Aerobic oxidation of $\alpha$-pinene catalysed by $\mathrm{Co}_{4} \mathrm{O}_{4}\left(\mathrm{O}_{2} \mathrm{CPh}\right)_{4}(4-\mathrm{CNpy})^{4}$.

GC analysis of products (figure 7) shows that the highest substrate conversion in the reactions is $81.4 \%$ with a turnover frequency (TOF) of 105 after $24 \mathrm{~h}$, while the selectivities for the epoxidation product, $\alpha$-pinene oxide, are in the range of $62-68 \%$. It can be seen that conversion and product yields are the highest when catalyst concentration is the lowest. This is in conformity with an earlier report where higher concentration of catalyst led to slower air oxidation of $\alpha$-pinene. ${ }^{27}$

\section{Conclusions}

It has been possible to develop a new general method for the synthesis of cobalt(III)-oxo cubane clusters of general formula $\mathrm{Co}_{4} \mathrm{O}_{4}\left(\mathrm{O}_{2} \mathrm{CR}\right)_{4} \mathrm{~L}_{4}$. Physicochemical behaviour of these soluble molecular complexes has been studied in detail. Molecular structure of the complexes has been analysed. A few complexes of the series have been evaluated as homogeneous catalysts for the oxidation of ethylbenzene, $p$-xylene and $\alpha$-pinene using dioxygen as the oxidant. The reactions

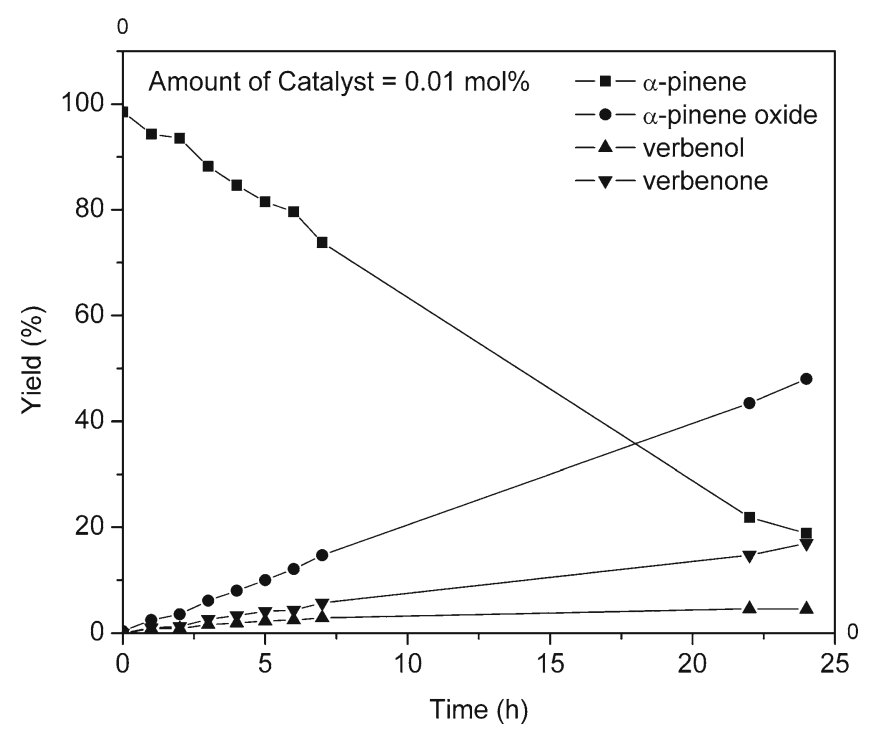

Figure 7. GC plots under optimized conditions for the catalytic oxidation of $\alpha$-pinene catalysed by a cubane complex of cobalt(III) ${ }^{13}$. lead to effective yields of desirable products at high selectivity under moderate liquid phase conditions. In view of the solubility of the complexes in alkyl aromatic substrates it is possible to carry out the oxidation reactions in the absence of added solvents. In one case it has been found that oxidation of $p$-xylene may also be carried out using water as a solvent. The promising catalytic behaviour shown by the complexes suggests that inclusion of more complexes in the studies may lead to even better results. The environmentally acceptable conditions used in the reactions indicate that with further investigations it may be possible to develop methods with potential for commercial exploitation.

\section{Supplementary information}

The electronic supporting information can be seen in www.ias.ac.in/chemsci.

\section{Acknowledgements}

Financial assistance from the Department of Science and Technology (DST), Government of India is gratefully acknowledged. RC thanks University Grants Commission (UGC), India for a Research Fellowship. The authors also thank Prof. JH Clark of the University of York, UK for his help and suggestions in doing the catalytic work.

\section{References}

1. Sheldon R A and Kochi J A 1981 Metal-catalyzed oxidations of organic compounds (New York: Academic Press)

2. Suresh A K, Sharma M M and Sridhar T 2000 Ind. Eng. Chem. Res. 393958

3. Chavan S A, Srinivas D and Ratnasamy P 2001 J. Catal. 204409

4. Sumner C E Jr and Steinmetz G R 1985 J. Am. Chem. Soc. 1076124

5. Sumner C E Jr and Steinmetz G R 1989 Inorg. Chem. 28 4290 
6. Winpenny R E P 2004 Comprehensive coordination chemistry (eds) J A McCleverty and T J Meyer (Oxford: Pergamon Press: 7 125)

7. Yagi M, Wolf K V, Baesjou P J, Bernasek S L and Dismukes G C 2001 Angew. Chem. Int. Ed. Engl. 40 2925

8. Chakrabarty R, Sarmah P, Saha B, Chakravorty S and Das B K 2009 Inorg. Chem. 486371

9. Chakrabarty R, Bora S J and Das B K 2007 Inorg. Chem. 469450

10. Sarmah P, Chakrabarty R, Phukan P and Das B K 2007 J. Mol. Catal. A Chem. 26836

11. Chakrabarty R, Das B K and Clark J H 2007 Green Chem. 9845

12. Chakrabarty R, Kalita D and Das B K 2007 Polyhedron 261239

13. Chakrabarty R and Das B K 2004 J. Mol. Catal. A Chem. 22339

14. Dimitrou K, Folting K, Streib W E and Christou G 1993 J. Am. Chem. Soc. 1156432

15. Beattie J K, Hambley T W, Klepetko J A, Masters A F and Turner P 1998 Polyhedron 171343

16. Das B K and Clark J H 2000 Chem. Commun. 605
17. Chakrabarty R 2006 Ph.D. Thesis, Gauhati University, Assam

18. Chakrabarty R, Bora S J and Das B K 2004 Catalysis in petroleum and petrochemicals industries (eds) A K Talukdar and K G Bhattacharyya (New Delhi: Narosa Publishing House) pp. 287-292

19. Ama T, Okamoto K, Yonemura T, Kawaguchi H, Takeuchi A and Yasui T 1997 Chem. Lett. 1189

20. Cotton F A and Willkinson G 1988 Advanced inorganic chemistry (New York: Wiley) 5th edn, pp. 735-738

21. Dimitrou K, Brown A D, Concolino T E, Rheingold A L and Christou G 2001 Chem. Commun. 1284

22. Partenheimer W 1995 Catal. Today 2369

23. Qi J-Y, Ma H-X, Li X J, Zhou Z-Y, Choi M C K, Chan, A S C and Yang O-Y 2003 Chem. Commun. 1294

24. Corma A, Iborra S and Velty A 2007 Chem. Rev. 107 2411

25. Gallezot P 2007 Catal. Today 12176

26. Maksimchuk N V, Melgunov M S, Chesalov Y A, Mrowiec-Białoń J, Jarzêbski A B and Kholdeeva O A 2007 J. Catal. 246241

27. Lajunen M K, Maunula T and Koskinen A M P 2007 Tetrahedron 568167 